\title{
A PRELIMINARY LIST OF THE MYXOMY- CETES OF THE CAYUGA LAKE BASIN
}

\author{
F. B. Wann and W. C. Muenscher
}

During the last five years the writers have made numerous collections of Myxomycetes in central New York, especially in the vicinity of Cornell University and Ithaca. These collections and many others which have been contributed by a number of collectors, as well as those available in the local herbaria, have been critically studied. In all, approximately 800 collections have been examined. The preliminary list given below is a record of all the species of Myxomycetes which the writers have seen and which are represented by material collected within the Cayuga Lake Basin.

The region covered by this list includes the territory drained by Cayuga Lake, the central lake of the Finger Lakes system of central New York. Roughly, the area includes a narrow strip averaging about eighteen miles in breadth, extending from Montezuma on the Erie Canal southward about sixty-five miles to Summit marsh in the northern part of Tioga County. The region includes the environs of Cornell University and the McLean Wild Life Preserve.

The list includes 92 species, in 30 genera and I f families. Varieties are not recorded individually. Lister $^{1}$ gives 49 genera in I 3 families for the world. The local representation of Myxomycetes would at first sight seem to be unusually large, but a more careful search will doubtless reveal many species in other localities with similar climatic conditions. The nomenclature used and the arrangement of species and genera under families adopted is essentially that used by Lister. ${ }^{1}$

The writers wish to acknowledge their indebtedness to the many persons who have contributed specimens to them from time to time; to Prof. H. H. Whetzel, who first suggested the work, for his constant interest and the many specimens contributed to us; to Prof. H. M. Fitzpatrick, for placing at our disposal for examina-

1 Lister, A. A Monograph of the Mycetozoa. Ed. 2. I9II. 
tion the Myxomycetes in the herbarium of the Department of Plant Pathology, New York State College of Agriculture, and also those in his private herbarium; to Prof. W. W. Rowlee, for giving us access to the collections in the herbarium of the Department of Botany of Cornell University; to Miss G. Lister, for verifying a number of doubtful specimens in the more difficult genera; and to Prof. T. H. Macbride, for his opinion regarding several collections.

The writers present this preliminary list, though incomplete, with the hope that it will stimulate interest in the discovery of other species which have not yet been seen from this locality.

\section{MYXOMYCETES OF THE CAYUGA LAKE BASIN}

\section{SubClass I.-Exosporeae}

Family i. Ceratiomyxaceae

Ceratiomyxa fruticulosa (Muell.) Macbr.

Ceratiomyxa porioides (Alb. and Schw.) Schroet.

\section{Subclass II.-Endos POREAE}

Family 2. Physaraceae

Badhamia macrocarpa (Ces.) Rost.

Badhamia rubiginosa (Chev.) Rost.

Badhamia utricularis (Bull.) Berk.

Craterium leucocephalum (Pers.) Ditm.

Craterium aureum (Schum.) Rost.

Diachaea leucopoda (Bull.) Rost.

Diachaea splendens Peck

Diderma effusum (Schw.) Morgan

Diderma globosum Pers.

Diderma spumarioides Fries

Diderma testaceum (Schrad.) Pers.

Fuligo septica (L.) Gmelin

Leocarpus fragilis (Dickson) Rost.

Physarum cinereum (Batsch) Pers.

Physarum citrinellum Peck

Physarum citrinum Schum.

Physarum compactum (Wing.) Lister

Physarum contextum Pers.

Physarum flavicomum Berk.

Physarum galbeum Wing.

Physarum globuliferum (Bu1l.) Pers.

Physarum leucopus Link

Physarum melleum (Berk. and Br.) Massee 
Physarum nucleatum Rex

Physarum nutans Pers.

Physarum polycephalum Schw.

Physarum pulcherrimum Berk. and Rav.

Physarum pulcripes Peck

Physarum rubiginosum Fries

Physarum sinuosum (Bull.) Weinm.

Physarum tenerum Rex

Physarum virescens Ditm.

Physarum viride (Bull.) Pers.

Family 3. Didymiaceae

Didymium clavus (Alb. and Schw.) Rost.

Didymium crustaceum Fries

Didymium difforme (Pers.) Duby

Didymium melanospermum (Pers.) Macbr.

Didymium squamulosum (Alb. and Schw.) Fries

Lepidoderma tigrinum (Schrad.) Rost.

Mucilago spongiosa (Leyss.) Morgan

Family 4. Stemonitaceae

Comatricha irregularis Rex

Comatricha longa Peck

Comatricha nigra (Pers.) Schroet.

Comatricha pulchella (Bab.) Rost.

Comatricha typhoides (Bull.) Rost.

Enerthenema papillatum (Pers.) Rost.

Lamproderma arcyrionema Rost.

Lamproderma columbinum (Pers.) Rost.

Lamproderma scintillans (Berk. and Br.) Morgan

Lamproderma violaceum (Fries) Rost.

Stemonitis ferruginea Ehrenb.

Stemonitis fusca Roth.

Stemonitis herbatica Peck

Stemonitis hyperopta Meylan

Stemonitis splendens Rost.

Family 5. Amaurochaetaceae

Brefeldia maxima (Fries) Rost.

Amaurochaete fuliginosa (Sow.) Macbr.

Family 6. Heterodermaceae

Cribraria argillacea Pers.

Cribraria aurantiaca Schrad.

Cribraria intricata Schrad.

Cribraria macrocarpa Schrad.

Cribraria purpurea Schrad.

Dictydium cancellatum (Batsch) Macbr.

Lindbladia effusa (Ehrenb.) Rost.

Family 7. Tubulinaceae

Tubifera ferruginosa (Batsch) Gmelin 


\section{$2 \mathrm{BHL}$ Biodiversity Heritage Library}

Wann, F. B. and Muenscher, W C. 1922. "A preliminary list of the myxomycetes of the Cayuga Lake basin." Mycologia 14(1), 38-41.

View This Item Online: https://www.biodiversitylibrary.org/item/173522

Permalink: https://www.biodiversitylibrary.org/partpdf/246307

\section{Holding Institution}

Smithsonian Libraries

\section{Sponsored by}

Biodiversity Heritage Library

\section{Copyright \& Reuse}

Copyright Status: Not in copyright. The BHL knows of no copyright restrictions on this item.

This document was created from content at the Biodiversity Heritage Library, the world's largest open access digital library for biodiversity literature and archives. Visit BHL at https://www.biodiversitylibrary.org. 